\title{
Protein FAM3C
}

National Cancer Institute

\section{Source}

National Cancer Institute. Protein FAM3C. NCI Thesaurus. Code C122079.

Protein FAM3C (227 aa, $25 \mathrm{kDa}$ ) is encoded by the human FAM3C gene. This protein is involved in the regulation of epithelial-to-mesenchymal transition. 